\title{
Variability of patient spine education by Internet search engine.
}

George M. Ghobrial, MD

Thomas Jefferson University

Angud Mehdi

Thomas Jefferson University Hospital

Mitchell Maltenfort, PhD

Thomas Jefferson University Hospital

Ashwini D Sharan, MD

Departments of Neurological Surgery, Thomas Jefferson University Hospitals

James Harrop, MD

Rothman Institute, Thomas Jefferson University

Follow this and additional works at: https://jdc.jefferson.edu/neurosurgeryfp

Part of the Medicine and Health Sciences Commons

Let us know how access to this document benefits you

\section{Recommended Citation}

Ghobrial, MD, George M.; Mehdi, Angud; Maltenfort, PhD, Mitchell; Sharan, MD, Ashwini D; and Harrop, MD, James, "Variability of patient spine education by Internet search engine." (2014). Department of Neurosurgery Faculty Papers. Paper 48.

https://jdc.jefferson.edu/neurosurgeryfp/48

This Article is brought to you for free and open access by the Jefferson Digital Commons. The Jefferson Digital Commons is a service of Thomas Jefferson University's Center for Teaching and Learning (CTL). The Commons is a showcase for Jefferson books and journals, peer-reviewed scholarly publications, unique historical collections from the University archives, and teaching tools. The Jefferson Digital Commons allows researchers and interested readers anywhere in the world to learn about and keep up to date with Jefferson scholarship. This article has been accepted for inclusion in Department of Neurosurgery Faculty Papers by an authorized administrator of the Jefferson Digital Commons. For more information, please contact: JeffersonDigitalCommons@jefferson.edu. 


\section{As submitted to:}

Clinical neurology and neurosurgery.

Variability of Patient Spine Education By Internet Search Engine

And later published as:

Volume 118, March 2014, pages: 59-64

DOI: 10.1016/j.clineuro.2013.12.013.

George M. Ghobrial M.D., ${ }^{1}$ Angud Mehdi, ${ }^{1}$ Mitchell Maltenfort PhD, ${ }^{2}$ Ashwini D. Sharan M.D., ${ }^{1}$ James S. Harrop M.D. ${ }^{1,3}$

1-Department of Neurological Surgery

Thomas Jefferson University Hospital

909 Walnut St.

${ }^{3 r d}$ Floor

Philadelphia, PA 19107

Work 215-955-7000

Fax 215-955-6565

2- Medical Statistician

Rothman Institute

Department of Orthopedic Surgery

3- Corresponding Author:

James S. Harrop, MD

Professor of Neurological Surgery

James.harrop@jefferson.edu

Phone: $215-955-7000$

Fax:215-503-7038

Key Words: spondylolisthesis, scoliosis, cauda equina, search engine, patient education

Abstract: 
BACKGROUND CONTEXT: Patients are increasingly reliant upon the internet as a primary source of medical information. The educational experience varies by search engine, search term, and changes daily. There are no tools for critical evaluation of spinal surgery websites. PURPOSE: To highlight the variability between common search engines for the same search terms. To detect bias, by prevalence of specific kinds of websites for certain spinal disorders. Demonstrate a simple scoring system of spinal disorder website for patient use, to maximize the quality of information exposed to the patient.

STUDY DESIGN: Ten Common Search terms were used to query three of the most common search engines. The top fifty results of each query were tabulated. A negative binomial regression was performed to highlight the variation across each search engine.

RESULTS: Google was more likely than Bing and Yahoo Search engines to return hospital ads $(\mathrm{P}=0.002)$ and more likely to return scholarly sites of peer-reviewed lite $(\mathrm{P}=0.003)$. Educational web sites, surgical group sites, and online web communities had a significantly higher likelihood of returning on any search, regardless of search engine, or search string $(\mathrm{P}=0.007)$. Likewise, professional websites, including hospital run, industry sponsored, legal, and peer-reviewed web pages were less likely to be found on a search overall, regardless of engine and search string $(\mathrm{P}=0.078)$.

CONCLUSION: The internet is a rapidly growing body of medical information which can serve as a useful tool for patient education. High quality information is readily available, provided that the patient uses a consistent, focused metric for evaluating online spine surgery information, as there is a clear variability in the way search engines present information to the patient. 
Introduction

Patients are obtaining a significant amount of their medical education prior to being evaluated by medical personnel. One large survey of orthopedic outpatients show a heavy reliance on internet searches for information on patient education.[1] This has particularly accelerated over the last decade due to the information age. The field of spine surgery has experienced this phenomena due to a number of factors. Presently, the patient preferred vessel for public education has been the internet. In particular, in the field of science and medicine, the rapid availability of medical news, literature via publications, and physician and hospital report cards are easily accessible through internet searches. New medical devices are heavily advertised online, which can alter patient perception of a disease and heighten expectations of surgery, prior to meeting the surgeon for the first consultation. Given the complexities of the field of spinal surgery, patient education is often driven chiefly by simplified medical education tools found through internet search engines. The first objective of this manuscript is to characterize the web sites that commonly return from key search terms such as cauda equina, epidural abscess, low back pain, spondylolisthesis, scoliosis, fusion, spinal surgery, sciatica, herniated disk, minimally invasive, laser spine surgery, and spinal cord injury. The goal of characterizing these key search terms is to demonstrate that a particular search term has web browser specific results from variations in search methodology that can lead to substantial bias in the types of web pages that return in the first fifty sites. The first sites that are returned in a browser arguably will have the greatest role in patient education.

Patient interactions with physicians are influenced by preconceived ideas they develop early in their quest for self-education. This is profoundly influenced by the search engine they 
have chosen. Therefore, a secondary goal in this manuscript is to offer patients a user-friendly method for rating surgery websites that offer information regarding spinal diseases.

Methods

An online internet search was conducted from September $1^{\text {st }}, 2012$ until September $30^{\text {th }}$, 2012 using the internet search engines Google ${ }^{\mathrm{TM}}$ (http://www.google.com), Yahoo ${ }^{\mathrm{TM}}$ (http://www.yahoo.com), and Bing ${ }^{\mathrm{TM}}$ (http://www.bing.com). A panel of neurosurgeons reviewed and selected common spine terminology and conditions and were frequent inquiries by patients seen on new referrals. Based on this evaluation ten selected terms were chosen which represented a spectrum of spinal diseases. Specifically, the following key terms were individually searched: cauda equina, epidural abscess, low back pain, spondylolisthesis, scoliosis, fusion, spinal surgery, sciatica, herniated disk, minimally invasive, laser spine surgery, and spinal cord injury. This search was in particular carried out by two undergraduate education students without a medical background, similar to the education of many commonly seen patients. The top fifty search results for each individual term were categorized as follows: educational site without advertisements, educational site with advertisements, medicolegal, hospital advertisement, industry, consumer, news, government, and surgical group. One division of web pages encompasses all professional websites that offer support for only a specific pathology, and that was labeled as 'web community'. Peer-reviewed, academic publications were also considered as a separate group. 
The top 50 results were categorized only for each search. For each search, the primary link was evaluated for each search return. A page was considered without advertisements if the page directly linked by the search engine did not include any banners or hyperlinks to consumer related products. Advertisements contained on webpages for products unrelated to the subject were included in the study as commercial advertisement. Websites containing banners from industrial, medicolegal, or healthcare consumer websites were considered separately. Web results involving animals were excluded from the study. Repeated webpages in the search were included in the tally based on the number of times they appeared in the top fifty for that particular search.

\section{Statistical Analysis}

A negative binomial regression was utilized. All three search engines were independently controlled for in order to compare results of Google, Yahoo, and Bing Searches. Log coefficients returned were compared by relative change and expressed as a percentage. A proprietary software package was utilized for statistical analysis ('R' $\mathrm{v}$. 2.15.1 by the R Foundation for Statistical Computing, Vienna Austria). Statistical significance was defined as a $\mathrm{P}$ value of 0.05 or less (confidence interval of $95 \%$ ).

Results

Distribution for the top fifty results of each search parameter are displayed according to search engine (Tables 1-3). Overall, educational sites with and without advertisements, surgical private groups, and online web community (dedicated to a particular healthcare goal) received most of the results irrespective of search engine (Figure 1). 
Controlling for Bing and Yahoo search engines, Google was more likely to return hospital ads $(\mathrm{P}=0.002)$ and more likely to return scholarly sites of peer-reviewed literature $(\mathrm{P}=0.003)$ than Bing or Yahoo search engines (Figure 4).

When controlling for type of search engine, educational web sites, surgical group sites, and online web communities had a significantly higher likelihood of returning on any search, regardless of search engine, or search string $(\mathrm{P}=0.007)$. Likewise, professional websites, including those hospital-run, industry-sponsored, legal, and peer-reviewed web pages were less likely to be found on a search overall, regardless of engine and search string $(\mathrm{P}=0.078)$.

\section{Discussion}

In our comparison of three popular search engines, some diseases did not have significantly different results using different search engines. This was the case with scoliosis where no statistically significant variance was demonstrated. The most common modalities of web information encounterd were educational sites and professional sites (Table 4). In a related inquiry by Mathur et al.[2], a predominance of academic sites in their tally of scoliosis sites on the web was noted. Still, they found the majority of all sites to be of poor academic quality, with few exceptions. This variation in quality was demonstrated on reviews of internet-based educational material for patients on topics such as back pain[3] and lumbar disc herniations.[4] However, spine websites that contain higher quality academic information may or may not be inviting to patients without a medical education and this should be taken into consideration.[5]

Across all three search engines, there was a high return for surgical private practice groups for the search terms spondylolisthesis, spine fusion, and spinal surgery. There was no 
statistical difference demonstrated in what search engine was chosen. The most biased and targeted search term by private practice websites was "laser spine surgery" which entailed 98 of 150 webpages $(65 \%)$. Unexpectedly, medicolegal websites were not highly prevalent in any of the spinal search terms. The search engine Google was more likely to return hospital ads, scholarly sites and hospital ads containing peer-reviewed literature as opposed to the search engines Bing or Yahoo $(\mathrm{P}=0.002)$. The present study illustrates that the choice of search engine utilized for spine education matters with regard to the modality of web page that will be encountered. The web sites were classified in this study into groups of modalities that were chosen by physicians and felt by the authors to represent the distinct mission of that particular website. It was the opinion of the physicians involved in this study that these different modalities each influence the patient in a different manner. Further patient-centered studies will be required to test that hypothesis.

While the internet has provided a growing forum for easy and unlimited access to the largest body of information, it is the major reservoir for new research as well as growing communities for specialized healthcare providers.[6] Thus, this information conduit and education algorithm has reshaped the patient-doctor relationship. Certainly, increased patient knowledge of a disease is helpful in that it eliminates barriers to informed consent, and increases the likelihood that a patient has found the best option for them.

Conversely, it can lead to preconceptions that are not necessarily true, and create new barriers for the physician-patient relationship. Qureshi and Colleagues[7] reviewed websites associated with marketing for cervical disc replacement technologies online, finding that $80 \%$ of these sites adequately described the potential benefits of the treatment, while only $40 \%$ went into 
detail describing the risk. They concluded that the availability of information of new surgical interventions was not without bias. One study regarding acoustic neuromas by Orabi et al. found that $24 \%$ of patients utilized the internet between 1997 and 2002 for education, with roughly $50 \%$ stating that they were influenced by the information prior to their first clinic consultation.[8] This influence is significant, and likely much more prevalent over a decade later.

However, without a guide, misinformation can be as prevalent as useful, peer-reviewed, medically relevant information when it comes to the internet. Lacking a simplified guide to spinal surgery-informative websites will provide misinformation leading to preconceptions. One of the only previous studies to evaluate the appropriateness of a spine website for its intended patient audience was by Sharan et al.[9] In it, 227 web pages were evaluated finding that roughly $80 \%$ were targeted for a patient level of education, $10 \%$ were physician-oriented, $6 \%$ were oriented to both, with the rest being unclassifiable. They had evaluated five common spinal diseases across five common websites. Li et al.[3] in a systematic review of 74 websites in 1996 for site related to back pain, found the majority to be of low-quality, and low accuracy, classifying a large amount as consumer-related. This trend of low quality and high variance is seen commonly amongst internet web sites. Given the heavy reliance of the present and future population on the internet for spinal education, a consensus system for grading internet webpages should be a consideration to promote higher quality educational sites.

Deshpande and colleagues[10] point out inherent difficulties to the process of establishing one simple algorithm for grading all medical websites. Not many solutions are in place for providing patients with a method for evaluating websites.[11] Jadad and 
colleagues[11] sought to comprehensively review all 47 evaluation tools for medical evidence on the web. They found that only 14 websites had a basic description of the grading scheme, and only 5 had description on how an individual could apply this grading scheme.[12,13] Presently only four of the five discussed rating instruments are available online today (Table 5).

One general tool, provided by the UK National Health Service[14] has been in place for over a decade, providing a methodology for grading health information. This lengthy tool evaluates medical literature by its general ability to define a specific question and establish a clear, concise process of answering that question, providing resources and references, as well as honestly establishing the unknown. Quality of medical evidence is not discussed in this tool. Weil et al[15] visited 600 spinal websites, utilizing a Global Quality Score (GQS) to assess the completeness, the accuracy, as well as the quality of healthcare information as it applies to cervical spinal surgery, find a corresponding score of excellent in only 6\%. The GQS is a composite score of ideal traits of a website that is effective in delivering high quality information, pulling from the European Criteria for Healthcare Related Medical Websites.[16] The highest quality of websites were more commonly associated with a professional society $(\mathrm{P}=0.021)$, which in our study was the second most encountered web site across the three search engines (Figure 4). Although professional societies had a higher than average GQS, the majority of the web pages were of a low GQS. The GQS suffers from its limitations in that it is very general, and could be improved by a more disease specific approach. While referring primary care physicians \could give the DISCERN, or GQS composite-based scoring system to a patient prior to their spine surgeon first visit, they could benefit more from a subspecialty-specific questionnaire that would help the patient navigate through their issues in an easier way. 
Intuitively, we can expect that the majority of these websites that are not hosted by a professional society, or a peer-reviewed academic society, will be biased in reporting, and also contain material with a low level of evidence.

Patients need a simple method for navigating webpages without being captivated by therapies that may or may not be realistic for them. Creating an internet grading scheme for classifying spine disease and their levels of evidence would help provide uniformity and make comparisons amongst sites more useful. Also, practicioners could gain a sense of the quality of the evidence themselves as they are visiting a particular website.

In our current study, the panel of neurosurgeons that had chosen the medical search terms chose diagnoses and search terms that they felt to be commonly asked about in the clinic. The authors did this to limit the educational bias. However, this is a limitation of this study that could not be completely overcome without involving patients in future surveys, by having patients list spine search terms via a questionnaire and then asking them to describe information about the modalities of websites that they visited.

As a corollary, the authors propose for a future validation study, a spine-specific grading scheme for universal evaluation of web sites in spinal surgery (Table 6). With a maximum score of 18 points, the patients can quickly record the scores from six key questions. Using this, more standardized comparisons between two websites can be made. Further interobserver and intraobserver validity would need to be carried out, which, surprisingly is unavailable for the other rating instruments. Correlating internet grading schemes with better patient outcomes[11] presumably by more informed choices is the ultimate goal of this research. 
Conclusion

The internet is a rapidly growing body of medical information which can serve as a useful tool for patient education. Variability in both the distribution and quality of educational materials is seen across varioius search engines. This should be stressed to patients using the internet as a primary educational material. A focused metric for evaluating online spine surgery information is needed, as there is a clear variability in the way search engines present information to the patient.

\section{Bibliography}

1. Kalichman SC, Benotsch E, Weinhardt L. Quality of health information on the Internet. JAMA : the journal of the American Medical Association 2001;286:2092-2093; author reply 2094-2095.

2. Mathur S, Shanti N, Brkaric M, Sood V, Kubeck J, Paulino C, Merola AA. Surfing for scoliosis: the quality of information available on the Internet. Spine 2005;30:2695-2700.

3. Li L, Irvin E, Guzman J, Bombardier C. Surfing for back pain patients: the nature and quality of back pain information on the Internet. Spine 2001;26:545-557.

4. Greene DL, Appel AJ, Reinert SE, Palumbo MA. Lumbar disc herniation: evaluation of information on the internet. Spine 2005;30:826-829.

5. Vives M, Young L, Sabharwal S. Readability of spine-related patient education materials from subspecialty organization and spine practitioner websites. Spine 2009;34:2826-2831.

6. Weinstein JN. Spine is expanding on the Internet. Spine 2001;26:125.

7. Qureshi SA, Koehler SM, Lin JD, Bird J, Garcia RM, Hecht AC. An evaluation of information on the internet about a new device: the cervical artificial disc replacement. Spine 2012;37:881-883.

8. Orabi AA, D'Souza AR, Walsh RR, Irving RM. The influence of the Internet on decision making in acoustic neuroma. The Journal of laryngology and otology 2005;119:806-809.

9. Sharan AD, Vaccaro AR, Albert TJ. Internet resources for spine surgeons. Journal of spinal disorders 2000;13:419-421.

10. Deshpande A, Jadad AR. Trying to measure the quality of health information on the internet: is it time to move on? The Journal of rheumatology 2009;36:1-3.

11. Jadad AR, Gagliardi A. Rating health information on the Internet: navigating to knowledge or to Babel? JAMA : the journal of the American Medical Association 1998;279:611-614.

12. Isham G. Prospects for radical improvement. The National Guidelines Clearinghouse project debuts on the Internet. Healthplan 1999;40:13-15. 
13. Fenton $\mathrm{SH}$, Badgett RG. A comparison of primary care information content in UpToDate and the National Guideline Clearinghouse. Journal of the Medical Library Association : JMLA 2007;95:255-259.

14. Service UKNH. The DISCERN Tool for Evaluating Health Information. Vol 2013. world wide web 1999.

15. Weil AG, Bojanowski MW, Jamart J, Gustin T, Leveque M. Evaluation of the quality of information on the Internet available to cervical spine surgery patients. World neurosurgery 2012.

16. eEurope 2002: Quality Criteria for Health Related Websites. Journal of medical Internet research 2002;4:E15.

\section{Tables}

Table 1. Google Internet Search (http://www.google.com), 9/10/2012

\begin{tabular}{|c|c|c|c|c|c|c|c|c|c|c|c|c|}
\hline $\begin{array}{l}\text { Search } \\
\text { Terms }\end{array}$ & $\begin{array}{l}\text { Educa } \\
\text { tional } \\
\text { (w/o } \\
\text { adver } \\
\text { tisem } \\
\text { ent) }\end{array}$ & $\begin{array}{l}\text { Educa } \\
\text { tional } \\
\text { (w/ } \\
\text { advert } \\
\text { iseme } \\
\text { nts) }\end{array}$ & $\begin{array}{l}\text { medic } \\
\text { olegal }\end{array}$ & $\begin{array}{l}\text { hospital } \\
\text { advertise } \\
\text { ment }\end{array}$ & $\begin{array}{l}\text { ind } \\
\text { ust } \\
\text { ry }\end{array}$ & $\begin{array}{l}\text { con } \\
\text { su } \\
\text { mer }\end{array}$ & $\begin{array}{l}\text { ne } \\
\text { ws }\end{array}$ & $\begin{array}{l}. \\
\text { g } \\
\text { o } \\
\mathbf{v}\end{array}$ & $\begin{array}{l}\text { web } \\
\text { community/o } \\
\text { rganization/a } \\
\text { cademic }\end{array}$ & $\begin{array}{l}\text { pee } \\
\text { r- } \\
\text { rev } \\
\text { iew } \\
\text { ed } \\
\text { arti } \\
\text { cle }\end{array}$ & $\begin{array}{l}\text { su } \\
\text { rgi } \\
\text { cal } \\
\text { gr } \\
\text { ou } \\
\text { p }\end{array}$ & $\begin{array}{l}\text { tot } \\
\text { al }\end{array}$ \\
\hline $\begin{array}{l}\text { cauda } \\
\text { equina }\end{array}$ & 12 & 3 & 3 & 5 & 0 & 0 & 0 & 1 & 15 & 7 & 4 & 50 \\
\hline $\begin{array}{l}\text { epidur } \\
\text { al } \\
\text { absces } \\
\text { s }\end{array}$ & 5 & 3 & 3 & 9 & 0 & 0 & 5 & 0 & 19 & 6 & 0 & 50 \\
\hline $\begin{array}{l}\text { low } \\
\text { back } \\
\text { pain }\end{array}$ & 12 & 5 & 2 & 4 & 0 & 0 & 3 & 0 & 17 & 7 & 0 & 50 \\
\hline $\begin{array}{l}\text { spondy } \\
\text { lolisthe } \\
\text { sis }\end{array}$ & 9 & 4 & 0 & 6 & 0 & 0 & 0 & 0 & 6 & 1 & 24 & 50 \\
\hline $\begin{array}{l}\text { scoliosi } \\
\text { s }\end{array}$ & 14 & 14 & 0 & 0 & 3 & 0 & 3 & 3 & 10 & 1 & 2 & 50 \\
\hline $\begin{array}{l}\text { spine } \\
\text { fusion }\end{array}$ & 4 & 4 & 3 & 7 & 1 & 2 & 2 & 2 & 8 & 3 & 14 & 50 \\
\hline
\end{tabular}




\begin{tabular}{|c|c|c|c|c|c|c|c|c|c|c|c|c|}
\hline $\begin{array}{l}\text { spinal } \\
\text { surgery }\end{array}$ & 12 & 10 & 0 & 1 & 1 & 1 & 2 & 4 & 3 & 1 & 15 & 50 \\
\hline sciatica & 10 & 20 & 1 & 2 & 1 & 0 & 0 & 6 & 6 & 1 & 3 & 50 \\
\hline $\begin{array}{l}\text { herniat } \\
\text { ed disk }\end{array}$ & 18 & 13 & 0 & 2 & 2 & 2 & 4 & 2 & 5 & 0 & 2 & 50 \\
\hline $\begin{array}{l}\text { minima } \\
\text { Ily } \\
\text { invasiv } \\
\text { e }\end{array}$ & 4 & 11 & 0 & 0 & 1 & 1 & 6 & 1 & 12 & 3 & 11 & 50 \\
\hline $\begin{array}{l}\text { laser } \\
\text { spine } \\
\text { surgery }\end{array}$ & 4 & 3 & 5 & 3 & 0 & 0 & 7 & 0 & 0 & 0 & 28 & 50 \\
\hline $\begin{array}{l}\text { spinal } \\
\text { cord } \\
\text { injury }\end{array}$ & 11 & 9 & 6 & 1 & 1 & 0 & 4 & 6 & 11 & 0 & 1 & 50 \\
\hline
\end{tabular}

Table 2. Bing Internet Search (http://www.bing.com), 9/10/2012

\begin{tabular}{|c|c|c|c|c|c|c|c|c|c|c|c|c|}
\hline $\begin{array}{l}\text { Search } \\
\text { Terms }\end{array}$ & $\begin{array}{l}\text { Educ } \\
\text { ation } \\
\text { al } \\
\text { (w/o } \\
\text { adver } \\
\text { tisem } \\
\text { ent) }\end{array}$ & $\begin{array}{l}\text { Educa } \\
\text { tional } \\
\text { (w/ } \\
\text { adver } \\
\text { tisem } \\
\text { ents) }\end{array}$ & $\begin{array}{l}\text { medic } \\
\text { olegal }\end{array}$ & $\begin{array}{l}\text { hospital } \\
\text { advertise } \\
\text { ment }\end{array}$ & $\begin{array}{l}\text { in } \\
\text { du } \\
\text { str } \\
y\end{array}$ & $\begin{array}{l}\text { con } \\
\text { su } \\
\text { me } \\
r\end{array}$ & $\begin{array}{l}\text { ne } \\
\text { ws }\end{array}$ & $\begin{array}{l}\text { gov } \\
\text { ern } \\
\text { men } \\
\text { t } \\
\text { (excl } \\
\text { udin } \\
\text { g } \\
\text { nat'l } \\
\text { lib. } \\
\text { Med } \\
\text {.) }\end{array}$ & $\begin{array}{l}\text { web } \\
\text { community/ } \\
\text { organization/ } \\
\text { academic }\end{array}$ & $\begin{array}{l}\text { pe } \\
\text { er- } \\
\text { rev } \\
\text { ie } \\
\text { we } \\
\text { d } \\
\text { arti } \\
\text { cle }\end{array}$ & $\begin{array}{l}\text { su } \\
\text { rgi } \\
\text { cal } \\
\text { gr } \\
\text { ou } \\
\text { p }\end{array}$ & \\
\hline cauda & 23 & 16 & 3 & 1 & 0 & 0 & 0 & 1 & 4 & 0 & 2 & 50 \\
\hline
\end{tabular}




\begin{tabular}{|c|c|c|c|c|c|c|c|c|c|c|c|c|}
\hline equina & & & & & & & & & & & & \\
\hline $\begin{array}{l}\text { epidur } \\
\text { al } \\
\text { absces } \\
\text { s }\end{array}$ & 25 & 6 & 2 & 2 & & & 1 & 2 & 10 & 2 & & 50 \\
\hline $\begin{array}{l}\text { low } \\
\text { back } \\
\text { pain }\end{array}$ & 14 & 19 & 0 & 2 & 3 & 0 & 1 & 4 & 6 & 0 & 1 & 50 \\
\hline $\begin{array}{l}\text { spondy } \\
\text { lolisth } \\
\text { esis }\end{array}$ & 22 & 18 & 0 & 0 & 0 & 0 & 0 & 2 & 4 & 0 & 4 & 50 \\
\hline $\begin{array}{l}\text { scoliosi } \\
\text { S }\end{array}$ & 10 & 11 & 0 & 0 & 6 & 0 & 3 & 3 & 14 & 1 & 2 & 50 \\
\hline $\begin{array}{l}\text { spine } \\
\text { fusion }\end{array}$ & 26 & 8 & 0 & 1 & 0 & 0 & 1 & 3 & 4 & 0 & 7 & 50 \\
\hline $\begin{array}{l}\text { spinal } \\
\text { surger } \\
\text { y }\end{array}$ & 14 & 12 & 0 & 0 & 1 & 1 & 3 & 0 & 4 & 0 & 15 & 50 \\
\hline $\begin{array}{l}\text { sciatic } \\
\text { a }\end{array}$ & 14 & 21 & 0 & 0 & 0 & 0 & 0 & 4 & 7 & 0 & 4 & 50 \\
\hline $\begin{array}{l}\text { herniat } \\
\text { ed disk }\end{array}$ & 17 & 12 & 0 & 1 & 1 & 0 & 5 & 4 & 7 & 0 & 3 & 50 \\
\hline $\begin{array}{l}\text { minim } \\
\text { ally } \\
\text { invasiv } \\
\text { e }\end{array}$ & 9 & 8 & 0 & 0 & 1 & 1 & 6 & 0 & 15 & 4 & 6 & 50 \\
\hline $\begin{array}{l}\text { laser } \\
\text { spine } \\
\text { surger } \\
\text { y }\end{array}$ & 8 & 7 & 0 & 0 & 0 & 1 & 3 & 0 & 1 & 0 & 30 & 50 \\
\hline $\begin{array}{l}\text { spinal } \\
\text { cord }\end{array}$ & 12 & 10 & 8 & 2 & 0 & 0 & 3 & 6 & 9 & 0 & 0 & 50 \\
\hline
\end{tabular}


injury

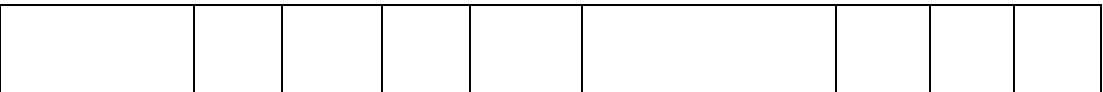

Table 3. Yahoo Internet Search (http://www.yahoo.com), 9/10/2012

\begin{tabular}{|c|c|c|c|c|c|c|c|c|c|c|c|c|}
\hline $\begin{array}{l}\text { Search } \\
\text { Terms }\end{array}$ & $\begin{array}{l}\text { Educ } \\
\text { ation } \\
\text { al } \\
\text { (w/o } \\
\text { adver } \\
\text { tisem } \\
\text { ent) }\end{array}$ & $\begin{array}{l}\text { Educa } \\
\text { tional } \\
\text { (w/ } \\
\text { adver } \\
\text { tisem } \\
\text { ents) }\end{array}$ & $\begin{array}{l}\text { medic } \\
\text { olegal }\end{array}$ & $\begin{array}{l}\text { hospital } \\
\text { advertise } \\
\text { ment }\end{array}$ & $\begin{array}{l}\text { in } \\
\text { du } \\
\text { str } \\
y\end{array}$ & $\begin{array}{l}\text { con } \\
\text { su } \\
\text { me } \\
r\end{array}$ & $\begin{array}{l}\text { ne } \\
\text { ws }\end{array}$ & $\begin{array}{l}\text { gov } \\
\text { ern } \\
\text { men } \\
t \\
\text { (excl } \\
\text { udin } \\
\text { g } \\
\text { nat'l } \\
\text { lib. } \\
\text { Med } \\
. \text {.) }\end{array}$ & $\begin{array}{l}\text { web } \\
\text { community/ } \\
\text { organization/ } \\
\text { academic }\end{array}$ & $\begin{array}{l}\text { pe } \\
\text { er- } \\
\text { rev } \\
\text { ie } \\
\text { we } \\
\text { d } \\
\text { arti } \\
\text { cle }\end{array}$ & $\begin{array}{l}\text { su } \\
\text { rgi } \\
\text { cal } \\
\text { gr } \\
\text { ou } \\
\text { p }\end{array}$ & \\
\hline $\begin{array}{l}\text { cauda } \\
\text { equina }\end{array}$ & 17 & 17 & 2 & 0 & 1 & 0 & 0 & 3 & 8 & 0 & 2 & 50 \\
\hline $\begin{array}{l}\text { epidur } \\
\text { al } \\
\text { absces } \\
\text { s }\end{array}$ & 20 & 6 & 0 & 2 & 0 & 0 & 1 & 3 & 17 & 1 & 0 & 50 \\
\hline $\begin{array}{l}\text { low } \\
\text { back } \\
\text { pain }\end{array}$ & 15 & 13 & 0 & 0 & 3 & 2 & 2 & 5 & 8 & 0 & 2 & 50 \\
\hline $\begin{array}{l}\text { spondy } \\
\text { lolisth } \\
\text { esis }\end{array}$ & 22 & 13 & 0 & 0 & 1 & 1 & 0 & 2 & 4 & 0 & 7 & 50 \\
\hline $\begin{array}{l}\text { scoliosi } \\
\text { s }\end{array}$ & 12 & 9 & 0 & 1 & 5 & 0 & 1 & 6 & 13 & 1 & 2 & 50 \\
\hline $\begin{array}{l}\text { spine } \\
\text { fusion }\end{array}$ & 25 & 9 & 0 & 1 & 0 & 0 & 2 & 3 & 2 & 0 & 8 & 50 \\
\hline $\begin{array}{l}\text { spinal } \\
\text { surger } \\
\text { y }\end{array}$ & 15 & 7 & 0 & 1 & 1 & 0 & 3 & 0 & 5 & 1 & 17 & 50 \\
\hline
\end{tabular}




\begin{tabular}{|c|c|c|c|c|c|c|c|c|c|c|c|c|}
\hline $\begin{array}{l}\text { sciatic } \\
a\end{array}$ & 20 & 20 & 0 & 0 & 0 & 0 & 0 & 1 & 6 & 0 & 3 & 50 \\
\hline $\begin{array}{l}\text { herniat } \\
\text { ed disk }\end{array}$ & 16 & 13 & 0 & 2 & 1 & 1 & 0 & 0 & 7 & 0 & 10 & 50 \\
\hline $\begin{array}{l}\text { minim } \\
\text { ally } \\
\text { invasiv } \\
\text { e }\end{array}$ & 4 & 9 & 0 & 0 & 3 & 1 & 0 & 2 & 11 & 2 & 18 & 50 \\
\hline $\begin{array}{l}\text { laser } \\
\text { spine } \\
\text { surger } \\
\text { y }\end{array}$ & 3 & 6 & 0 & 0 & 0 & 1 & 2 & 0 & 3 & 0 & 35 & 50 \\
\hline $\begin{array}{l}\text { spinal } \\
\text { cord } \\
\text { injury }\end{array}$ & 10 & 9 & 8 & 1 & 1 & 0 & 3 & 6 & 10 & 0 & 2 & 50 \\
\hline
\end{tabular}

Table 4. Variations in Modality of Spine Education Seen between Web Browsers

\begin{tabular}{|l|l|l|l|l|}
\hline Web Page Type & Google & Bing & Yahoo & $\begin{array}{l}\text { P(differance } \\
\text { between } \\
\text { browsers) }\end{array}$ \\
\hline $\begin{array}{l}\text { Educational } \\
\text { (w/o } \\
\text { advertisements) }\end{array}$ & 115 & 179 & 194 & $2.00 \mathrm{E}-16$ \\
\hline $\begin{array}{l}\text { Educational (w/ } \\
\text { advertisements) }\end{array}$ & 112 & 94 & 85 & $4.90 \mathrm{E}-13$ \\
\hline $\begin{array}{l}\text { Medicolegal } \\
\text { advertisement }\end{array}$ & 23 & 10 & 13 & 0.00901 \\
\hline $\begin{array}{l}\text { Hospital } \\
\text { Adver }\end{array}$ & 10 & 8 & 9 & 0.07931 \\
\hline Industry & 16 & 12 & 0.00233 \\
\hline
\end{tabular}




\begin{tabular}{|l|l|l|l|l|}
\hline & & & & \\
\hline Consumer & 6 & 6 & 3 & $1.85 \mathrm{E}-07$ \\
\hline News & 36 & 14 & 26 & 0.53301 \\
\hline $\begin{array}{l}\text { Government } \\
\text { Community/ } \\
\text { Academic } \\
\text { owned }\end{array}$ & 25 & 31 & 29 & 0.46781 \\
\hline $\begin{array}{l}\text { Peer Reviewed } \\
\text { Journal }\end{array}$ & 30 & 94 & 85 & $2.80 \mathrm{E}-08$ \\
\hline $\begin{array}{l}\text { Surgical } \\
\text { practice }\end{array}$ & 104 & 5 & 74 & 0.0041 \\
\hline \begin{tabular}{l} 
Seb \\
\hline
\end{tabular} & 106 & $7.97 \mathrm{E}-09$ \\
\hline
\end{tabular}

Table 5. Summary of Healthcare Rating Instruments for the Web with Instructions for Use

\begin{tabular}{|c|c|c|c|}
\hline Rating Instrument & URL & Method & $\begin{array}{l}\text { Validity } \\
\text { /Reliability } \\
\text { Study? }\end{array}$ \\
\hline $\begin{array}{l}\text { Quality Criteria } \\
\text { for Health Related } \\
\text { Websites, } \\
\text { established by the } \\
\text { European } \\
\text { Community (EC } \\
\text { Criteria) }^{1}\end{array}$ & $\begin{array}{l}\text { http://eur- } \\
\text { lex.europa.eu/LexUriServ/L } \\
\text { exUriServ.do?uri=COM:200 } \\
\text { 2:0667:FIN:EN:PDF }\end{array}$ & $\begin{array}{l}\text { Emphasizes transperancy: } \\
\text { author, funding, use of data, } \\
\text { and aim stated clearly. }\end{array}$ & No \\
\hline $\begin{array}{l}\text { Argus } \\
\text { Clearinghouse }^{5}\end{array}$ & $\begin{array}{l}\text { http://www.clearinghou } \\
\text { se.net/ratings.htm }\end{array}$ & $\begin{array}{l}\text { Rates the ability of website to } \\
\text { hold answers for nonexpert }\end{array}$ & No \\
\hline
\end{tabular}




\begin{tabular}{|l|l|l|l|}
\hline & & searchers & \\
\hline DISCERN $^{12}$ & Weil et al. $^{15}$ & $\begin{array}{l}\text { General tool assessing if aim } \\
\text { of website is clearly and } \\
\text { coherently achieved }\end{array}$ & No \\
\hline $\begin{array}{l}\text { Health on the Net } \\
\text { Foundation }\end{array}$ & $\begin{array}{l}\text { http://www.hon.ch/HON } \\
\text { code/Conduct.html }\end{array}$ & $\begin{array}{l}\text { 8 point criteria: author } \\
\text { qualifications, purpose, } \\
\text { references, clarity, and } \\
\text { sources of funding are } \\
\text { highlighted. }\end{array}$ & No \\
\hline
\end{tabular}

Table 6. Quality of Evidence Evaluation for Spine Surgery (Maximum Score 18 points)

\begin{tabular}{|c|c|c|c|}
\hline Questions & 1 & 2 & 3 \\
\hline Are claims referenced? & No & $\begin{array}{l}\text { Incomplete/ } \\
\text { unable to find } \\
\text { any } \\
\text { references. }\end{array}$ & Yes \\
\hline $\begin{array}{l}\text { Is the main purpose of this site } \\
\text { to sell surgical equipment? }\end{array}$ & yes & $\begin{array}{l}\text { Unclear, } \\
\text { multiple } \\
\text { banners and } \\
\text { links to sell } \\
\text { equipment }\end{array}$ & No \\
\hline $\begin{array}{l}\text { Does this website provide } \\
\text { resources for litigation? }\end{array}$ & Yes & - & No \\
\hline $\begin{array}{l}\text { Is the main purpose of this } \\
\text { website to promote/disseminate } \\
\text { medical publication? }\end{array}$ & No & $\begin{array}{l}\text { Unclear, } \\
\text { results from } \\
\text { medical } \\
\text { publications } \\
\text { are present. }\end{array}$ & Yes \\
\hline $\begin{array}{l}\text { Is the spinal therapy offered, } \\
\text { explained clearly, with }\end{array}$ & No & $\begin{array}{l}\text { Referenced, } \\
\text { but without }\end{array}$ & Yes, easily \\
\hline
\end{tabular}




\begin{tabular}{|l|l|l|l|}
\hline $\begin{array}{l}\text { references to literature } \\
\text { publications? }\end{array}$ & $\begin{array}{l}\text { clear } \\
\text { explanation. }\end{array}$ & understandable. \\
\hline $\begin{array}{l}\text { Are treatments/therapies } \\
\text { discussed with specific regard to } \\
\text { improvement in back or leg } \\
\text { pain? }\end{array}$ & No & $\begin{array}{l}\text { Yes, but } \\
\text { treatment } \\
\text { regarded as } \\
\text { absolute } \\
\text { (cure). }\end{array}$ & $\begin{array}{l}\text { Yes, with } \\
\text { references to } \\
\text { likelihood of } \\
\text { improvement in } \\
\text { specific } \\
\text { symptom. }\end{array}$ \\
\hline
\end{tabular}

